\title{
Customer Satisfaction with Less than Container Load Cargo Services in HoChiMinh City, Vietnam
}

\author{
Ha Nam Khanh GIAO', Nguyen Thi Anh THY', Bui Nhat VUONG ${ }^{3}$, Tran Ngoc TU ${ }^{4}$, \\ Pham Quang VINH ${ }^{5}$, Le Thi Phuong LIEN ${ }^{6}$
}

Received: May 26, 2020 Revised: May 31, 2020 Accepted: July 09, 2020

\begin{abstract}
This research has four specific objectives: (1) identifying factors that affect customer satisfaction with less than container load (LCL) cargo services of logistics companies in HoChiMinh City (HCMC), (2) measuring the level of impact of the factors, (3) testing the difference in satisfaction among groups of customers with different characteristics in terms of type of business and time of using LCL cargo services, and (4) proposing some management implications to improve the quality of LCL cargo services. Researchers interviewed 210 customers who enjoyed the LCL cargo service in HCMC for at least the last six months, using the convenient sampling method. SPSS 20 was used to analyze the reliability of the scale through the Cronbach's alpha coefficient, then exploratory factor analysis and multiple linear regression analysis were used. The results identified the six factors that influence positively customer satisfaction of LCL cargo services of logistics companies in HCMC, by decreasing importance: service process, image, resource, price, management, and outcomes. The results show that there is no difference in customer satisfaction with LCL cargo services by types of business as well as time of using services. The research suggests some implications for the management of logistics companies in HCMC to enhance customer satisfaction.
\end{abstract}

Keywords: Cargo Services, Customer Satisfaction, Less Than Container Load (LCL), Logistics Companies

JEL Classification Code: C12, C83, M16, M31, R41

\section{Introduction}

${ }^{1}$ First Author and Corresponding Author. Dean, Faculty of Air Transport, Vietnam Aviation Academy, Vietnam [Postal Address: A65 Nam Thong 1 Town, Phu My Hung Zone, Tan Phu Ward, District 7, Ho Chi Minh City, 72908, Vietnam] Email: khanhgiaohn@yahoo.com

${ }^{2}$ Head, Department of Accounting and Finance, Vietnam Aviation Academy, Vietnam. Email: thynta@vaa.edu.vn

'Lecturer, Faculty of Air Transport, Vietnam Aviation Academy,

Vietnam. Email: nhatvuong1@gmail.com

${ }^{4}$ Lecturer, Faculty of Business Administration, Saigon University,

Vietnam. Email: tranngoctu1984@gmail.com

${ }^{5}$ Deputy Chief, Department of Facilities Administration, Saigon University, Vietnam. Email: vinhpham.hcm@gmail.com

${ }^{6}$ Deputy Chief, Foreign Languages - Informatics Center, University of Banking, Vietnam. Email: phuongliendhnh@gmail.com

(c) Copyright: The Author(s)

This is an Open Access article distributed under the terms of the Creative Commons Attribution Non-Commercial License (http://Creativecommons.org/licenses/by-nc/4.0/) which permits unrestricted noncommercial use, distribution, and reproduction in any medium, provided the original work is properly cited.
Vietnam has joined the World Trade Organization (WTO), ASEAN, and most recently ratified the CPTPP, which has created a foundation for the development of the country's trade in general and the shipping industry in particular. In 2019, Vietnam's total export-import reached USD337.22 billion, growing at $8.1 \%$ (accounting for USD25.18 billion) compared to the same period in 2018 . According to the report No. 94/BC-BCT of the Ministry of Industry and Trade, there are more than 4,000 businesses involved in freight forwarder and logistics, on any type of transportation: railway, airway, seaway, roadway, inland waterway, and multimodal transportation. This shows that the supply may exceed the demand in the coming years, and the competition in the shipping industry among the shipping lines is increasingly fierce.

Based on the report No. 94/BC-BCT of the Ministry of Industry and Trade, Chung (2019) said that more than $70 \%$ of logistics companies have head offices and representative offices and branches in HoChiMinh City; the big names are SNP, Gemadept, Transimex, IndoTrans, TBS Logistics, New 
Port Saigon, Delta, U\&I Logistics, Sotrans, Minh Phương Logistics, Ecu Worlwide, ATT Logistics, among others. Therefore, the survey of customers' opinions to improve the service quality is needed. This research is conducted to measure customer satisfaction of logistics companies in HCMC, Vietnam.

\section{Literature Review}

\subsection{Service Quality and Customer Satisfaction}

Several researchers have contributed to the understanding of service quality and customer satisfaction as two distinct constructs. Earlier researchers mostly considered either the effect of service quality or the effect of satisfaction on behavioral intentions. Such studies may lead to biased results, which potentially overstate the importance of one or both of these variables in the development of behavioral intentions and, therefore, confound the antecedent role of service quality and satisfaction. Perceptions of service quality and customer satisfaction are viewed as attitudinal constructs. Service quality in the marketing literature is considered as a cognitive process. Satisfaction in service environments is an affective state that results from the cognitive process as well as the affective process, and the outside communications. There isn't a convergent view on the relative roles of these two constructs. One view considers customer satisfaction to be an independent construct affecting customer behavior (Dabholkar, 1995; Iacaobucci et al., 1994), while another considers customer satisfaction to be a determinant of service quality (Bitner, 1990; Mohar \& Bitner, 1995). However, the conceptualization that customer satisfaction is a mediating variable in the service quality-customer satisfaction-behavioral intentions framework has received more empirical support and acceptance in the recent services marketing literature (Cronin, Brady \& Hult, 2002; Kang \& James, 2004).

From 2000s, researchers normally accept that service quality and customer satisfaction are two very closely related and sometimes even identified concepts. Customer satisfaction is a key factor in assessing the quality of a service. If it is difficult to define the quality of service, it is even harder to determine the level of customer satisfaction. Caceres and Paparoidamis (2007), Gorla, Somers and Wong (2010) argue that service quality is the predecessor of customer satisfaction. It can therefore be assumed that the quality of service leads to customer satisfaction. However, there is no doubt that both of these elements - service quality and customer satisfaction - are generally recognized as the major decisive factors in maintaining long-term and successful business relationships (Jayawardhena, 2010; Hoang, Igel, \& Laosirihongthong, 2010; Rahman, 2008).
Thus, both logistics service quality and customer satisfaction are especially important in the current business environment, as the relationship between the service provider and the client is usually long-term. One of the most significant elements in service markets is the support and development of relationship with the customer (Caceres \& Paparoidamis, 2007). For the relationship to be long-term, a logistics service provider has to provide a service in line with the customers' expectations, leading to the appropriate level of customer satisfaction.

It is important for logistics companies, while carrying their activities, to show that their actions and deeds are concentrated on customers. Zairi (2000), analyzing customer satisfaction, indicates that customers comprise the aim of the company's activity, i.e., he focuses on the fact that no service users and customers depend on the company, but the company's performance depends on its existing customers. Wirtz (2001) also stresses that customer satisfaction becomes the key element companies focus on to seek to promote repeated business relationships and increase long-term profitability. Other authors (Panayides, 2007; Liu \& Xie, 2013) argue that in the current competitive environment it is dangerous to be a non-customer-oriented company. Most of the companies are competitive, who must provide high-quality services that would make customers satisfied and loyal. It also should be considered that logistics service companies should know their customers to have more opportunities to make right decisions on the needs of the client; it allows companies to develop new services that provide real value to customers as well as to assess quantitatively the values desired by customers.

Jaiswal (2008) generally defines customer satisfaction as a customer assessment in terms of whether the service meets the customer's needs and expectations. It is important to note that each client's expectations are different. This may depend not only on the personal interests, but also on the environment, area, and the type of business in which those expectations are formed. Thus, companies' ability to be flexible and adaptable may help to gain an advantage over other business entities. Examining logistics services, flexibility is a particularly important aspect. Flexibility in logistics is the possibility of a company to quickly and effectively respond to the changing needs of the client (Autry, Zacharia, \& Lamb, 2008; Juga, Juntunen, \& Grant, 2010).

\subsection{Logistics Service Quality and Customer Satisfaction}

Many scholars paid attention to services in general and service quality in particular. Quality of service, as a concept, raises a high interest among scientists and researchers, as the quality of service is not only difficult to define, but to measure as well (Zeithaml \& Bitner, 2000; Parasuraman, 
Zeithaml \& Berry, 1981, 1991; Gronroos, 1984, Giao, Hoai \& Vinh, 2019; Giao, 2004, 2018f; Oliver, 1993; Kotler \& Amstrong, 2012, Autry, Zacharia, \& Lamb, 2008; Bhargava \& Sun, 2008; Brah \& Lim, 2006; Breja, Banwet, \& Iyer, 2011; Hoang, Igel, \& Laosirihongthong, 2010; Juga, Juntunen, \& Grant, 2010; Tse \& Tan 2011). The main definitions of quality of service focus on the fact that the service has to meet the customer's needs and expectations (Liu \& Xie, 2013; Breja, Banwet, \& Iyer, 2011) and is interpreted as a difference of terms of service provision and customers' expectations of perceived service. If the customer's expectations are higher than the result of the service process, then the customer perceives the service quality is not satisfactory (Huang, Wang, \& Xue, 2012). Most of the research is about personal services (Giao \& Vuong, 2020; Vuong \& Giao, 2019; Giao \& Lien, 2018; Giao \& Mo, 2018; Giao, Vuong, Huan, Tushar \& Quan, 2020; Giao, 2017; Giao, Vuong \& Quan, 2018; Giao, Duong \& Tu, 2018; Giao, Hoang \& Vinh, 2018), not so much research is about business services (Giao, Trung \& Truong, 2019; Giao, 2018e, Bartels, Giao \& Ohlenburg, 2006)

Logistics service quality is the result of comparing customers' expectations with customers' perception of service quality. Clients, prior to ordering the service, already have expectations of what the service provider should offer them. Therefore, the quality of logistics service perceived by the client is the difference between the perceived service and expectation (Campos \& No'brega, 2009).

The quality of service is closely related to customer expectations. In today's competitive environment, the pursuit of customer satisfaction highly depends on the organization's overall service quality. According to many authors (Chee \& Noorliza, 2010; Chen, Chang, \& Lai, 2009; Huang \& Huang, 2012; Jaiswal, 2008; Jayawardhena, 2010; Juga, Juntunen, \& Grant, 2010; Kilibarda, Zečcvic, \& Vidovic, 2012; Panayides, 2007; Giao, 2020, 2018a, 2018b, 2018c, 2018d, 2018g, 2018h, 2019a, 2019b, 2019d), satisfaction of customers' expectations regarding service quality affects business performance and encourages customer loyalty. The satisfaction of customer expectations is generally seen as a positive opinion of the client about the service after the service is performed. In other words, this is an evaluation of the results of the process.

Recently, Vinh and Grewal (2005) used ROPMIS model to measure logistics service in Australia, including six factors: (1) Resource, (2) Outcomes, (3) Process, (4) Management, (5) Image, and (6) Corporate Social Responsibility. In Vietnam, where social responsibility is not an easy-to-measure construct, scholars have tried not to mention it in their studies. Based on ROPMIS, Tuyen (2012) and Giao and Ai (2012) identified three factors: (1) Image and resource-based capability, (2) Service process and management, and (3) Price. Based on SERVPERF scale, Duyen (2014) recognized six factors impacting on customer satisfaction: (1) Reliability, (2) Assurance, (3) Responsiveness, (4) Empathy, (5) Tangibles, and (6) Price, while Giao et al. (2019) singled out outbound service quality at Wan Hai Lines, based on SERVPERF scale. Dung (2020) identified six factors impacting on customer satisfaction of LCL imported cargo at Ecu worldwide: (1) Outcomes, (2) Price, (3) Service process, (4) Management, (5) Image, and (6) Resource.

\subsection{Proposed Research Model and Hypotheses}

Inheriting the previous study results, especially from SERVPERF scale (Cronin \& Taylor (1994), and ROPMIS model (Thai \& Grewal, 2005), Tuyen (2012), Duyen (2014), Zeithaml (1988), Vinh (2017), Giao et al. (2019), Dung (2020), the proposed research model is presented in Figure 1.

$\boldsymbol{H}_{1}$ : The customers' perception of outcomes affects directly and positively the level of satisfaction of LCL cargo services of logistics companies in HCMC.

$\boldsymbol{H}_{2}$ : The customers' perception of service process affects directly and positively the level of satisfaction of LCL cargo services of logistics companies in HCMC.

$\boldsymbol{H}_{3}:$ The customers' perception of management affects directly and positively the level of satisfaction of LCL cargo services of logistics companies in HCMC.

$\boldsymbol{H}_{4}$ : The customers' perception of image affects directly and positively the level of satisfaction of LCL cargo services of logistics companies in HCMC.

$\boldsymbol{H}_{5}:$ The customers 'perception of resource affects directly and positively the level of satisfaction of LCL cargo services of logistics companies in HCMC.

$\boldsymbol{H}_{6}:$ The customers' perception of price affects directly and negatively the level of satisfaction of $L C L$ cargo services of logistics companies in HCMC.

\section{Methodology}

The study employs a cross-sectional research design. Variables in the study are overall service quality and customer satisfaction. The customer satisfaction survey is conducted in two phases: in the first stage, initial date was collected and evaluated; in the second stage, the customer satisfaction index was calculated by using Cronbach's alpha, EFA and linear regression analysis.

\section{Results and Discussion}

\subsection{Sample Description Statistics}

After interviewing directly and online 225 business customers (mostly chiefs of export-import department/ division of companies) who have utilized LCL cargo services 
for at least the last six months using convenient sampling method, 210 valid survey samples meeting the requirements were included in the official study (see Table 1).

\subsection{Testing Scale Reliability}

After analyzing Cronbach's Alpha, the scales met the criteria (Cronbach's Alpha coefficient $\geq 0.6$ and correlation variable coefficient - total correction $\geq 0.3$ ) (see Table 2).
Therefore, it is used to analyze the next EFA. There are 27 observable variables grouped in seven factors in the scales.

\subsection{Exploratory Factor Analysis (EFA)}

Using extraction method as Principal Component Analysis and Varimax with Kaiser Normalization as rotation method, the EFA for the independent variables shows the $\mathrm{KMO}$ coefficient $=0.901>0.5$ with $\mathrm{Sig}=0.000<0.05$,

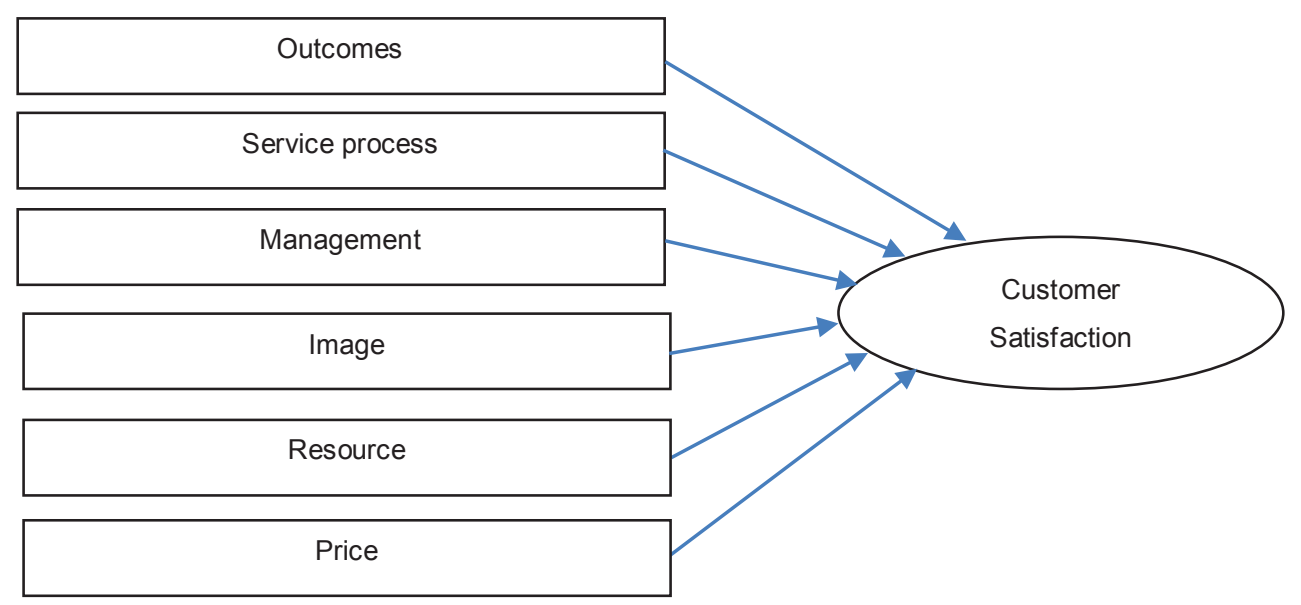

Figure 1: Proposed research model

Table 1: Official survey sample information

\begin{tabular}{|l|l|c|c|}
\hline \multicolumn{1}{|c|}{$\mathbf{N}=\mathbf{2 1 0}$} & Number & \% \\
\hline \multirow{3}{*}{ Types of business } & Manufacturing and Trading & 146 & 70 \\
\cline { 2 - 4 } & Other logistics and freight forwarder companies & 64 & 30 \\
\hline \multirow{3}{*}{$\begin{array}{l}\text { Time of using LCL cargo } \\
\text { service }\end{array}$} & Under 1 yr & 23 & 11,5 \\
\cline { 2 - 4 } & From 1 to under 3 yr & 61 & 30,5 \\
\cline { 2 - 4 } & From 3 to under 5 yr & 33 & 16,5 \\
\cline { 2 - 4 } & $5 \mathrm{yr}$ and over & 83 & 41,5 \\
\hline
\end{tabular}

Table 2: Results of the reliability calculation of the scale

\begin{tabular}{|l|l|c|c|c|}
\hline \multicolumn{1}{|c|}{ No } & \multicolumn{1}{|c|}{ Scale } & $\begin{array}{c}\text { No of observable } \\
\text { variables }\end{array}$ & Cronbach's Alpha & $\begin{array}{c}\text { Smallest Item-Total } \\
\text { Correlation }\end{array}$ \\
\hline 1 & Image (IMA) & 4 & .926 & .672 \\
\hline 2 & Outcomes (OUT) & 6 & .888 & .718 \\
\hline 3 & Service process (SP) & 4 & .901 & .732 \\
\hline 4 & Management (MNGT) & 4 & .943 & .822 \\
\hline 5 & Resource (RES) & 3 & .842 & .688 \\
\hline 6 & Price (PRI) & 3 & .771 & .778 \\
\hline 7 & Customer Satisfaction (CS) & 3 & .926 & .792 \\
\hline
\end{tabular}


Table 3: Results of EFA of service quality factors

\begin{tabular}{|c|c|c|c|c|c|c|}
\hline \multirow{2}{*}{ Observable variables } & \multicolumn{6}{|c|}{ Factor loading } \\
\hline & 1 & 2 & 3 & 4 & 5 & 6 \\
\hline $\mathrm{OUT}_{2}$ & .824 & & & & & \\
\hline $\mathrm{OUT}_{4}$ & .806 & & & & & \\
\hline $\mathrm{OUT}_{3}$ & .799 & & & & & \\
\hline $\mathrm{OUT}_{5}$ & .793 & & & & & \\
\hline $\mathrm{OUT}_{6}$ & .791 & & & & & \\
\hline OUT $_{1}$ & .664 & & & & & \\
\hline $\mathrm{MNGT}_{3}$ & & .769 & & & & \\
\hline $\mathrm{MNGT}_{2}$ & & .725 & & & & \\
\hline $\mathrm{MNGT}_{4}$ & & .714 & & & & \\
\hline $\mathrm{MNGT}_{1}$ & & .711 & & & & \\
\hline $\mathrm{SP}_{3}$ & & & .715 & & & \\
\hline $\mathrm{SP}_{1}$ & & & .676 & & & \\
\hline $\mathrm{SP}_{2}$ & & & .671 & & & \\
\hline $\mathrm{SP}_{4}$ & & & .661 & & & \\
\hline $\mathrm{IMA}_{2}$ & & & & .670 & & \\
\hline $\mathrm{IMA}_{3}$ & & & & .662 & & \\
\hline $\mathrm{IMA}_{1}$ & & & & .618 & & \\
\hline $\mathrm{IMA}_{4}$ & & & & .614 & & \\
\hline $\mathrm{PRI}_{3}$ & & & & & .729 & \\
\hline $\mathrm{PRI}_{2}$ & & & & & .716 & \\
\hline $\mathrm{PRI}_{1}$ & & & & & .707 & \\
\hline $\mathrm{RES}_{1}$ & & & & & & .818 \\
\hline $\mathrm{RES}_{3}$ & & & & & & .811 \\
\hline $\mathrm{RES}_{2}$ & & & & & & .767 \\
\hline \multicolumn{7}{|l|}{ Post EFA testing } \\
\hline Eigenvalue & 14.335 & 2.209 & 2.121 & 1.564 & 1.225 & 1.059 \\
\hline $\begin{array}{l}\text { Average Variance } \\
\text { Extracted }(\%)\end{array}$ & 44.797 & 6.902 & 6.629 & 4.888 & 3.828 & 3.309 \\
\hline Cronbach's Alpha & 0.943 & 0.915 & .888 & .901 & 0.842 & 0.771 \\
\hline
\end{tabular}

indicating that the observed variables belong closely to the same factor correlating. Also, the total extracted variance of $77.779 \%>50 \%$ shows that these six factors explain $77.779 \%$ the variation of the dataset and Eigenvalue $=1.405$ $>1$ (Giao \& Vuong, 2019) qualifying factor analysis (see Table 3).

Using extraction method as Principal Axis Factoring and Promax with Kaiser Normalization as rotation method, the EFA of the dependent variable group showed that KMO and Bartlett's in the analysis of factors have sig. $=0.000$ and $\mathrm{KMO}=0.505>0.5$; The Eigenvalue value is 1.742
$>1$. Therefore, the extracted scales are acceptable. All three observed variables have factor loadings greater than 0,5. Thus, the scale satisfies the convergence value and reliability (Giao \& Vuong, 2019).

\subsection{Correlation Analysis}

Test of $\mathrm{r}$ correlation coefficient results shown in Table 4 with meaning level of 0.01 (reliability 99\%) of all six components of independent variable scale correlate with customer satisfaction, so they can be put into regression. 
Table 4: Pearson correlation

\begin{tabular}{|l|c|c|c|c|c|c|c|}
\hline & CS & IMA & OUT & SP & MNGT & RES & PRI \\
\hline CS & 1 & $.618^{* *}$ & $.662^{* *}$ & $.686^{* *}$ & $.545^{* *}$ & $.392^{* *}$ & $.793^{* *}$ \\
\hline IMA & $.618^{* *}$ & 1 & $.632^{* *}$ & $.679^{* *}$ & $.666^{* *}$ & $.251^{* *}$ & $.663^{* *}$ \\
\hline OUT & $.662^{* *}$ & $.632^{* *}$ & 1 & $.538^{* *}$ & $.554^{* *}$ & $.266^{* *}$ & $.808^{* *}$ \\
\hline SP & $.686^{* *}$ & $.679^{* *}$ & $.538^{* *}$ & 1 & $.646^{* *}$ & $.280^{* *}$ & $.648^{* *}$ \\
\hline MNGT & $.545^{* *}$ & $.666^{* *}$ & $.554^{* *}$ & $.646^{* *}$ & 1 & $.240^{* *}$ & $.641^{* *}$ \\
\hline RES & $.392^{* *}$ & $.251^{* *}$ & $.266^{* *}$ & $.280^{* *}$ & $.240^{* *}$ & $.274^{* *}$ \\
\hline PRI & $.793^{* *}$ & $.663^{* *}$ & $.808^{* *}$ & $.648^{* *}$ & $.641^{* *}$ & $.274^{* *}$ & 1 \\
\hline${ }^{* *}$. Correlation is significant at the 0.01 level (2-tailed) & & & \\
\hline
\end{tabular}

Table 5: Results of the regression analysis

\begin{tabular}{|c|c|c|c|c|c|c|c|}
\hline \multirow{2}{*}{ Model } & \multicolumn{2}{|c|}{ Unstandardized coefficient } & \multirow{2}{*}{$\begin{array}{c}\text { Standardized coefficient } \\
\text { Beta } \\
\end{array}$} & \multirow{2}{*}{$t$} & \multirow{2}{*}{$\begin{array}{c}\text { Level of } \\
\text { Significance }\end{array}$} & \multicolumn{2}{|c|}{ Multicollinearity } \\
\hline & B & Standard error & & & & Tolerance & VIF \\
\hline (Constant) & -.042 & .200 & & -.212 & .832 & & \\
\hline IMA & .400 & .052 & .399 & 7.714 & .000 & 0.565 & 1.771 \\
\hline OUT & .030 & .055 & .028 & .548 & .058 & 0.583 & 1.717 \\
\hline SP & .379 & .040 & .436 & 9.384 & .000 & 0.598 & 1.673 \\
\hline MNGT & .038 & .052 & .038 & .734 & .046 & 0.668 & 1.496 \\
\hline RES & .158 & .048 & .151 & 3.265 & .001 & 0.653 & 1.531 \\
\hline PRI & -.048 & .032 & -.052 & -1.489 & .013 & 0.795 & 1.258 \\
\hline \multicolumn{2}{|l|}{ Adjusted $\mathrm{R}^{2}$} & \multicolumn{6}{|c|}{0.788} \\
\hline \multicolumn{2}{|c|}{ Durbin - Watson } & \multicolumn{6}{|c|}{2.031} \\
\hline \multicolumn{2}{|l|}{$\mathrm{F}$} & \multicolumn{6}{|c|}{130.539} \\
\hline \multicolumn{2}{|l|}{ sig } & \multicolumn{6}{|c|}{0.000} \\
\hline
\end{tabular}

\subsection{Multiple Regression Analysis}

Table 5 shows that the adjusted $\mathrm{R}^{2}$ is 0.788 , ie $78.8 \%$ the variation of CS explained by variation of 6 independent variables OUT, MNGT, SP, IMA, RES, PRI. Durbin - Watson $\mathrm{d}=2.031(1<\mathrm{d}<3)$ showed no correlation between residuals. The sig. value of $F(=130.539)$ equals to 0.000 , ie the linear regression model given is consistent with the collected data (Giao \& Vuong, 2019). We have the unstandardized regression model as follows:

\section{$C S=-0.42+0.400 * I M A+0.030 * O U T+0.379 * S P+$ $0.038 * M N G T+0.158 * R E S-0.048 * P R I$}

We see that $\beta_{3}>\beta_{1}>\beta_{5}>\beta_{6}>\beta_{4}>\beta_{2}$ so that the factors that affect the overall satisfaction of service quality are in the descending order: $\mathrm{SP}>\mathrm{IMA}>\mathrm{RES}>\mathrm{PRI}>\mathrm{MNGT}>\mathrm{OUT}$.

\subsection{Regression Assumption Testing}

The residual test showed that the residual distribution was approximately standard with Mean $=0$ and standard deviation $=0.975$ (approx. 1$)$, so it can be concluded that the standard distribution hypothesis is not violated when using multiple regression.

On the other hand, the results also show that the residuals of the model have a bell-shaped down-righted graph, so the residuals of the model have a normal distribution. In addition, according to the P-P plot diagram, the observation points are not scattered too far from the expected line, so the normal distribution of the residuals is not violated. According to the Scatterplot graph, the regression errors are distributed evenly on both sides of the average (zero errors) and do not follow a clear rule, it means that the error hypothesis of the constant regression model is appropriate. So, with the above 
results, we find that the regression model is consistent and statistically significant (Giao \& Vuong, 2019).

\subsection{Difference Testing}

The purpose of this analysis is to find differences in the quality of service assessment from factors presented in Table 1. In this section, ANOVA and T-test are used. The results show that there is no difference in customer satisfaction with LCL cargo services of logistics companies in HCMC by types of business as well as time of using service.

\subsection{Testing the Hypotheses}

The results of testing hypotheses from correlation analysis between independent variables of service quality satisfaction and the dependent variable is significant at $95 \%$ confidence level, all hypotheses are accepted (see Table 6).

\section{Recommendations and Conclusion}

\subsection{Management Implications}

\subsubsection{About Service Process}

This is the strongest factor affecting customer satisfaction of LCL cargo services of logistics companies in HCMC. The general mean of this factor is 3.818 (out of 5), implying that customers are satisfied at a rather high level. Customer insight is another factor that keeps customers stay longer with the business. The company needs to enhance the listening and sharing of customers' wishes and special attention to customers' specific requirements such as prolonging the time of delivery to the port, time for correction of documents, and emptying containers near the factory area to reduce container towing costs.

When conflict occurs, the problem should be viewed objectively, in the spirit of priority to solve the problem for the goods, ensuring the interests of customers in the spirit of constant cooperation with customers. If problems arise, deferred debt of many customers with large amount of goods; stability is also a way to support customers significantly, helping customers to avoid rushing payment to receive documents and goods. Large customers, stable inventory, the company supporting a 30-day deferred debt, all contribute to increase the ability to reduce payment pressure immediately.

Some companies nowadays invest deeply in management information system, such as Ecu Worldwide that invested in the TOPAZ system from 2018, one of the top IT system in logistics, which can connect all the agencies worldwide of Ecu Line Group. These companies needs to offer training courses to upgrade staff capabilities to explore the systems effectively (Giao, 2019).

\subsubsection{About Image}

The general mean of this factor is 4.005, implying that customers are satisfied at a rather high level. In terms of reliability, in order to ensure the proper delivery of the service to the customer, the company needs to manage the subcontractors well. The company has to outsource trucking. The status of subcontractors that does not provide the service as committed, such as delayed car, or failing to provide sufficient driver information, will affect the plan and the arrangement of the customer. Therefore, the company needs to

Table 6: Results of hypothesis testing

\begin{tabular}{|c|l|c|c|}
\hline \multicolumn{1}{|c|}{ Hypotheses } & Regression Coefficient & Testing result \\
\hline $\mathrm{H}_{1}$ & $\begin{array}{l}\text { The customers' perception of outcomes affects directly and positively the } \\
\text { level of satisfaction of LCL cargo services of logistics companies in HCMC. }\end{array}$ & $\begin{array}{c}0,030 \\
(>0)\end{array}$ & Accepted \\
\hline $\mathrm{H}_{2}$ & $\begin{array}{l}\text { The customers' perception of service process affects directly and positively } \\
\text { the level of satisfaction of LCL cargo services of logistics companies in } \\
\text { HCMC }\end{array}$ & $\begin{array}{c}0,436 \\
(>0)\end{array}$ & Accepted \\
\hline $\mathrm{H}_{3}$ & $\begin{array}{l}\text { The customers' perception of management affects directly and positively } \\
\text { the level of satisfaction of LCL cargo services of logistics companies in } \\
\text { HCMC }\end{array}$ & $\begin{array}{c}0,038 \\
(>0)\end{array}$ & Accepted \\
\hline $\mathrm{H}_{4}$ & $\begin{array}{l}\text { The customers' perception of image affects directly and positively the level } \\
\text { of satisfaction of LCL cargo services of logistics companies in HCMC }\end{array}$ & $\begin{array}{c}0,400 \\
(>0)\end{array}$ & Accepted \\
\hline $\mathrm{H}_{5}$ & $\begin{array}{l}\text { The customers' perception of resource affects directly and positively the } \\
\text { level of satisfaction of LCL cargo services of logistics companies in HCMC }\end{array}$ & $\begin{array}{c}0,158 \\
(>0)\end{array}$ & Accepted \\
\hline $\mathrm{H}_{6}$ & $\begin{array}{l}\text { The customers' perception of price affects directly and negatively the level } \\
\text { of satisfaction of LCL cargo services of logistics companies in HCMC }\end{array}$ & $\begin{array}{c}-0.048 \\
(<0)\end{array}$ \\
\hline
\end{tabular}


evaluate and review the quality of services of subcontractors every three months to make timely adjustments.

Besides, the company needs to train staff in knowledge and skills in the field of logistics and supply chain management, helps staff to ensure good connections with port authorities and colleagues in other companies, especially in Vietnam Logistics Association (VLA) in order to catch up with changes, new requirements, new rules and new application in logistics; this is also a way to enhance the company's image in the industry. The company also needs to consider applying marketing methods to build up and project the company brand in the industry so that the customers are aware and feel the company can be a reliable partner.

\subsubsection{About Resource}

The general mean of this factor is 3.005, implying that customers are satisfied at an average level. Resource factors (such as transaction counters, human resources, website and agency systems, and office space) are also important factors contributing to customer satisfaction. Convenient trading desks will help customers to trade quickly. At present, the company is gradually improving a shorter transaction time, with the goal of a maximum of five minutes' wait when customers pick up bill of loading and delivery orders, thus, contributing to shorten the time for customers.

The company should advertised the name and title of the employee, so that customers can contact him/her again next time. Besides, the lighting system at the counter should also be added so that the counter becomes more eyecatching, brighter and luxurious, thereby creating added value, increasing professionalism and, therefore, increasing customers satisfaction.

Along with the increasing development of shipping and electronic logistics, the website is an indispensable tool. The company's website must be updated with new functions so that customer can look up merchandise information and updates on related fields. The website is a useful tool where customers can check direct information about the shipment anywhere, so that customers do not need to call or email to check, significantly reducing the time. However, even though a number of customers know the website and how to find information there, most of them keep traditional habits at work, that is, direct contact with the staff by email or telephone. Therefore, there is a delay in responding to the customer for not receiving the email or working hours, resulting in costs to customers and unnecessary disputes. Therefore, to overcome the above situation, when dealing with customers, employees need to be introduced to the website and specific instructions for access to customers, so that customers can update the status of goods wherever they are. This is also considered a way to create value added services for customers, with which they will be more satisfied with the service of the company. The company may permitting staff to use social networks such as Skype, Zalo, Viber, Gmail, etc., to connect to customers frequently, officially or semi-officially, so that customers feel the convenience; that will help to enhance customer satisfaction.

In recent years, the company has focused on training and developing human resources. The company should send staff to attend courses such as Customs, industry seminars, etc., to be updated on the new regulations, to improve skills, as well as staying on top of the general market trends. The goal should be world-class logistics to support customers on a timely manner, contributing to increased customer satisfaction.

\subsubsection{About Price}

The general mean of this factor is 2.39 , implying that customers are satisfied at a rather low level. Customers can compare all the price list of the companies and find out that the pricing strategies are quite different, sometimes they do not have a clear pricing strategy at all. So, the company should consider a suitable and sustainable pricing strategy, with which the company needs to do promotion such as frequentbuyer bonus, peak and low season pricing, and announcing foreign agencies pricelist to help customers choose the right logistics company. In addiction, the company can launch PR campaigns to build a solid social capital with customers, which can help to overcome customers' price sensitivity.

Recently Li, Chen and $\mathrm{Li}$ (2018), doing research on pricing models of logistics distribution services for perishable commodities, noted no consideration was given to the influence of season, weather, distribution mode of transportation, deliver region, etc., and relationships among them, which are crucial and should be studied in future. They identified four main models (see Table 7), which can contribute to different average profit outcomes. Comparing the four pricing models, they found that the average profit of a logistics service provider under the fixed pricing model with time constraints is higher than that under the fixed pricing model alone. The average profit of the logistics

Table 7: Optimal price and average profit in four models

\begin{tabular}{|c|l|c|}
\hline No & Optimal Price (RMB) & Average Profit (RMB) \\
\hline 1 & Fixed Pricing Model & 69,96 \\
\hline 2 & $\begin{array}{l}\text { Fixed Pricing Model with } \\
\text { Time Constraints }\end{array}$ & 79,58 \\
\hline 3 & Dynamic Pricing Model & 67,17 \\
\hline 4 & $\begin{array}{l}\text { Dynamic Pricing Model } \\
\text { with Time Constraints }\end{array}$ & 70,77 \\
\hline
\end{tabular}

(Source: Li, Chen \& Li, 2018) 
service provider under the dynamic pricing model with time constraints is higher than that under the dynamic pricing model alone. The average profit of the logistics service provider under the dynamic pricing model with time constraints is higher than that under other three models. Besides, they also found that customers are more inclined to choose the dynamic pricing model with or without time constraints. For the two dynamic models mentioned above, consumer service satisfaction is more important to the quantity of distribution, and it indirectly affects the overall profit. Therefore, for these two models, logistics service providers should pay more attention to the response of customers, or take more active measures to improve their own consumer service satisfaction. This should be a good information channel for the company to consider when building up pricing strategy.

\subsubsection{About Management}

The general mean of this factor is 3.818 , implying that customers are satisfied at a rather high level. Thus, the company first needs to focus on improving the proactive communication with customers about the changes related to the shipment. Whenever there is any information regarding shipment delays such as ship delays, vessel delays, etc., the company staff will immediately notify the customer, as well as the parties involved, so that all parties have timely information. Whenever it occurs, it will be the customer's representative to work with the shipping company and the parties involved to protect the interests of the customer.

With logistics in general and the shipping industry in particular, two key factors that make up that advantage are time and cost. Understanding this, the company sets the criteria for all customer requirements for quick response. Specifically, employees should reply to the email within 15 minutes after receiving the request of the customer, or will immediately call the customer to confirm in emergency, to avoid incurring costs to guests, such as editing the document after the data transfer period. With the current customer response time of 2 hours, this is considered a significant improvement, contributing to the increase in serviceability and quality of service provided by the company, thereby increasing customer satisfaction.

In some cases, customers have problems arising from their errors such as errors in customs clearance or inward transportation not being timely. In order to complete the customs formalities, the company will support customers working with the parties to catch the ship, try to secure the lowest cost (if any). In peak seasons, the company needs to have a plan for preparation and redundancy to minimize employee overload, and minimize delays and errors when serving customers. The company may recruit more employees or allow employees to work overtime, and also have compensation policies for devoted employees to work overtime to keep their work as well as customer service at a satisfactory level.

Warranty is also an important factor for customers to be confident when using the service of the company. The company always check and monitor the goods to ensure delivery on time, in the right place, the right quantity and ensure the status of goods upon reception. Every year, the company needs to conduct a customer survey to find out what is the quality of service the company is offering, how satisfied or dissatisfied the customers are, etc., and collect the comments of customers (Giao, Hang, Phuong, Vuong, Tuan, Vinh, \& Tu, 2020).

\subsubsection{About Outcomes}

Amazingly, this is the weakest factor impacting on customer satisfaction of LCL cargo services of logistics companies in HCMC, with a general mean of 3.588, implying that customers assesses this not highly. The thorough handling of complaints remains the biggest wish of the customer. In transportation, sometimes there is an occurrence of force majeure or loss or damage of goods. Therefore, a company's branch should set up a division to resolve complaints and compensation for customers, so that they can resolve quickly and provide satisfactory support to customers. In addition, the company should have a record of customer contributions, as well as complaints and grievance redress, so that every employee can know how to resolve the issues that arise for full satisfaction, to increase the prestige of the company, as well as enhance customers' satisfaction.

Besides, the company needs to consider spreading its social network and social capital to support customers in emergency cases and for special services needed such as customs declaration, cargo moving from Container Freight Station (CFS) to their plant, surcharges, etc. The company needs to develop these in a professional manner as well as provide $24 / 7$ services without any extra charge.

\subsection{Conclusions}

This study was conducted with the objective of measuring the impact on customer satisfaction of LCL cargo services of logistics companies in Ho Chi Minh City. The research was conducted through a combination of qualitative and quantitative methods with a valid sample size of 210. Scales were verified by Cronbach's alpha reliability analysis, EFA, Pearson correlation analysis, multiple regression analysis, and the impact test of demographic variables. Research results show that the most influential factors on customer satisfaction is Reliability, the second most influential factor is Service process, followed by Image, Resource, Price, Management, and Outcomes. The results show that there is 
no difference in customer satisfaction of LCL cargo services of logistics companies in HCMC by types of business as well as time of using service.

\subsection{Limitations and Suggestions for Further Studies}

The study's limitations are as follows: (1) the topic is to study only customer satisfaction of LCL cargo services of logistics companies in HCMC, so there will be limitations in offering solutions to improve the other logistics services such as FCL, charter, etc., (2) the convenient sampling method was used, so the representativeness is not high, and (3) the results only explain $78.8 \%$ of the variable value of customer satisfaction of LCL cargo services of logistics companies in HCMC, this points to other factors that might have an effect above and beyond those mentioned in this study. These limitations call for further research directions.

\section{References}

Autry, C., Zacharia, Z., \& Lamb, C. (2008). A logistics strategy taxonomy. Journal of Business Logistics, 29(2), 27-51. http:// dx.doi.org/10.1002/j.2158-1592.2008.tb00086.x

Bartels, F., Giao, H. N. K., \& Ohlenburg, T. J. (2006). ASEAN Multinational Enterprises: A Structural Analysis of Strategic Coherence. ASEAN Economic Bulletin, 23(2), 171-191. DOI: 10.31219/osf.io/eqfuw.

Bhargava, H. K., \& Sun, D. W. (2008). Pricing under quality of service uncertainty: market segmentation via statistical QoS guarantees. European Journal of Operational Research, 191(3), 1189-1204. http://dx.doi.org/10.1016/j.ejor.2007.07.013

Bitner, M. J. (1990). Evaluating service encounters: the effects of physical surroundings and employee responses. Journal of Marketing, 54, 69-82.

Brah, S. A., \& Lim, H. Y. (2006). The effect of technology and $\mathrm{TQM}$ on the performance of logistics companies. International Journal of Physical Distribution \& Logistics Management, 36(3), 192-209. http://dx.doi.org/10.1108/09600030610661796

Breja, S. K., Banwet, D. K., \& Iyer, K. C. (2011). Quality strategy for transformation: A case study. The TQM Journal, 23(1), 5-20. http://dx.doi.org/10.1108/17542731111097452

Caceres, R. C., \& Paparoidamis N. G. (2007). Service quality, relationship satisfaction, trust, commitment and business-tobusiness loyalty. European Journal of Marketing, 41(7/8), 836-867.http://dx.doi.org/10.1108/0309056071075242

Campos, D. F., \& No'brega, K. C. (2009). Importance and the zone of tolerance of customer expectations of fast food services. Journal of Operations and Supply Chain Management, 2(2), 56-71

Chee, Y. W., \& Noorliza, K. (2010). Explaining the competitive advantage of logistics service provider: A resource-based view approach. International Journal of Production Economics, 128(1), 51-67. http://dx.doi.org/10.1016/j.ijpe.2009.08.026

Chen, K., Chang, C., \& Lai, C. (2009). Service quality gaps of business customers in the shipping industry. Transportation Research Part E, 45, 222-237. http://dx.doi.org/10.1016/j. tre.2008.02.005

Chung, T. (2019). More than 70\% logistics companies concentrate on HoChiMinh City and the nearby areas. Retrieved Jan 20, 2020 from http://tphcm.chinhphu.vn/70-doanh-nghieplogistics-tap-trung-o-tphcm-va-vung-lan-can.

Cronin, J. J, Brady, M. K., \& Hult, G. T. M. (2000). Assessing the effects of quality, value, and customer satisfaction on consumer behavioural intentions in service environment. Journal of Retailing, 76(2), 193-218

Cronin, J. J., \& Taylor, S. A. (1992). Measuring Service Quality: Reexamination and Extension. Journal of Marketing, 56, 55-68.

Dabholkar, P. A. (1995). A contingency framework for predicting causality between customer satisfaction and service quality. In: R. Kardes and M. Sujan (Eds.), Advances in consumer research (pp. 101-108), UT: Association for Consumer Research.

Dung, V. M. T. (2020). Factors effecting customer satisfaction of less than container load imported cargo service at Ecu worldwide. Masters thesis, Vietnam: Vietnam Aviation Academy.

Duyen, B. T. M. (2014). Measuring customer satisfaction of LCL exported cargo service of the LCL companies. Masters thesis, Vietnam: Vietnam Aviation Academy.

Giao, H. N. K., \& Vuong, B. N. (2019). Textbook for Master Degree Research Methods in Business- Updated with SmartPLS. Hanoi: Finance Publishing. DOI: 10.31219/osf.io/hbj3k.

Giao, H. N. K., Hoai, A. T., \& Vinh, P. Q. (2019). Management of Services Business- From the Angle of Marketing. Hanoi: Communication - Information Publishing. DOI: 10.31219/osf. io/98hrd.

Giao, H. N. K., \& Ai, T. H. (2012). The Affects of Service Quality on the Loyalty of Customers who Use ADSL in HCMC. Economic Development Review, 256(February), 34-44. DOI: 10.31219/osf.io/ypxfm

Giao, H. N. K., \& Lien, L. T. P. (2018). The factors effect the English training at the foreign languages - Informatics Center, University of Banking, HoChiMinh City, Vietnam. Global and Stochastic Analysis, 5(6), 340-352. DOI: 10.31219/osf.io/ rnuad.

Giao, H. N. K., \& Mo, N. T. H. (2018). Factors influencing consumers' impulse television buying decision at Best Buy Vietnam (BBVN). Global and Stochastic Analysis, 5(6), 353369. DOI: 10.31219/osf.io/cgz2x

Giao, H. N. K., Vuong, B. N., Huan, D. D., Tushar, H., \& Quan, T. N. (2020). The Effect of Emotional Intelligence on Turnover Intention and the Moderating Role of Perceived Organizational Support: Evidence from the Banking Industry of Vietnam. Sustainability, 12(5), 1857-1882. DOI: 10.3390/su12051857. 
Giao, H. N. K., \& Vuong, B. N. (2020). Vietnamese Consumer Attitudes towards Smartphone Advertising. Journal of Asian Finance, Economics and Business, 7(5), 195-204. https://doi. org/10.13106/jafeb.2020.vol7.no5.195

Giao, H. N. K. (2004). Services Marketing- 5 Gaps in Services Quality Model. (Vietnamese). Hanoi, Vietnam: Statistical Publishing.

Giao, H. N. K. (2017). Customer Satisfaction and Quality of Vietnam Airline Domestic Services. International Journal of Quality Innovation, 3(1), 1-11, DOI: 10.1186/s40887-0170019-4.

Giao, H. N. K. (2018a). Vietnamese consumers' attitude on television advertisement of skin care. National Academy of Managerial Staff of Culture and Arts Herald, 4, 486-491. DOI: 10.31219/osf.io/a2bn9.

Giao, H. N. K. (2018b). Decision to choose fast food restaurants of the young people in HCMC, Vietnam. National Academy of Managerial Staff of Culture and Arts Herald, 4, 471-485. DOI: 10.31219/osf.io/xgv2k.

Giao, H. N. K. (2018c). Decision to purchase online airline tickets in Ho Chi Minh City, Vietnam. National Academy of Managerial Staff of Culture and Arts Herald, 4, 459-470. DOI: 10.31219/ osf.io/fzh5v.

Giao, H. N. K. (2018d). Factors Influencing Customer Behavior of Butter Oil Substitute in Vietnam. Journal of Business and Economics, 9(3), 266-274, DOI: 10.15341/jbe(21557950)/03.09.2018/005.

Giao, H. N. K. (2018e). Measuring service quality in construction project management service at AIC Management Co., Ltd. - A dimension-by-dimension analysis. International Journal of Applied Business and Economic Research, 16(1), 165-175. DOI: $10.31219 /$ osf.io/bf5ke.

Giao, H. N. K. (2018f). Monographic Book Measuring Service Quality in Vietnam-from the Customers Angle. Hanoi, Vietnam: Finance Publishing. DOI: 10.31219/osf.io/cqh68.

Giao, H. N. K. (2018g). Satisfaction and word-of-mouth at the language centers in Vietnam. International Journal of Applied Business and Economic Research, 16(2), 427-433. DOI: 10.31219/osf.io/etvjd.

Giao, H. N. K. (2018h). Study of the Factors Affecting Customers' Loyalty for Gym Service at K.I.M Center, Vietnam. International Journal of Scientific Engineering and Research, 6(12), 67-76. DOI: 10.31219/osf.io/57g8a.

Giao, H.N.K. (2019a). Attitude and Intention to buy VietGAP vegetables of inhabitants in HoChiMinh City. International Journal of Agricultural Economics, 4(3), 125-134. DOI: 10.11648/j.ijae.20190403.16.

Giao, H. N. K. (2019b). Customer Satisfaction towards ATM Services: A Case of Vietcombank Vinh Long, Vietnam. Journal of Asian Finance, Economics and Business, 6(1), 141-148. http://doi.org/10.13106/jafeb.2019.vol6.no1.141
Giao, H. N. K. (2019c). Textbook for Master Degree Management of Information System- from the Business Angle. Hanoi, Vietnam: Finance Publishing. DOI: 10.31219/osf.io/uxyw3.

Giao, H. N. K. (2019d). The effect of corporate culture on the staff's commitment in CMC Telecom Vietnam. Science Journal of Business and Management, 7(1), 23-32. DOI: 10.11648/j. sjbm.20190701.14.

Giao, H. N. K. (2020). Customer Satisfaction at Tiki.vn E-Commerce Platform. Journal of Asian Finance, Economics and Business, 7(4), 173-183. https://doi.org/10.13106/jafeb.2020.vol7. no4.173

Giao, H. N. K. Vuong, B. N., \&d Quan, T. N. (2019). The influence of website quality on consumer's e-loyalty through the mediating role of e-trust, esatisfaction, and perceived enjoyment: An evidence from online shopping in Vietnam. Uncertain Supply Chain Management, 8(2), 351-370. DOI: 10.5267/j.uscm.2019.11.004.

Giao, H. N. K., Duong, P. N., \& Tu, T. N. (2018). Research on Consumer Behavior of Wine in HoChiMinh City. Global and Stochastic Analysis, 5(8), 111-122. DOI: 10.31219/osf. io/4cvn7.

Giao, H. N. K., Hang, N. T. H, Phuong, N. N. D., Vuong, B. N., Tuan, H. Q., Vinh, P. Q., \& Tu, T. N., 2020. Textbook for Master Degree Strategic Management - Updated with BSC. Hanoi, Vietnam: Finance Publishing. ISBN: 978-604-79-2372-4

Giao, H. N. K., Hoang, C. C., \& Vinh, P. Q. (2018). Factor affecting buying decision of Amalie lubricants in Vietnam. Global and Stochastic Analysis, 5(8), 137-150. DOI: 10.31219/osf.io/ $\operatorname{kgc56.}$

Giao, H. N. K., Kiem, D., Son, L. T., \& Dung, T. Q. (2018). Satisfaction of tourists to Hoi An ancient town, Vietnam. Global and Stochastic Analysis, 5(8), 123-136. DOI:10.31219/ osf.io/sbjev.

Giao, H. N. K., Trung, B., \& Truong, P. Q. (2019). Outbound service quality at Wan Hai Lines. Journal of Asian Finance, Economics and Business, 6(1), 177-185. http://doi.org/10.13106/ jafeb.2019.vol6.no1.177

Gorla, N., Somers, T. M., \& Wong, B. (2010). Organizational impact of system quality, information quality, and service quality. Journal of Strategic Information Systems, 19, 207-228. http://dx.doi.org/10.1016/j.jsis.2010.05.001

Hoang, D., T., Igel, B., \& Laosirihongthong, T. (2010). Total quality management (TQM) strategy and organisational characteristics: Evidence from a recent WTO member. Total Quality Management \& Business Excellence, 21, 931-951. http://dx.doi.org/10.1080/14783363.2010.487680

Huang, B., Wang, T., \& Xue, X. (2012). Service-selecting approach based on domain-specified 'Quality of Service' model and its application in logistics. The Service Industries Journal, 32(9), 1571-1588. http://dx.doi.org/10.1080/02642069.2010.551761

Huang, C. J., \& Huang, K. P. (2012). The logistics capabilities scale for logistics service providers. Journal of Information and 
Optimization Sciences, 33(1), 135-148. http://dx.doi.org/10.10 80/02522667.2012.10700139

Iacobucci, D., Ostrom, A. L., \& Grayson, K. A. (1994). The calculus of service quality and customer satisfaction: theoretical and empirical differentiation and integration. In: T. A. Swartz, D. H. Bowen, \& S. W. Brown (Eds.), Advances in services marketing and management (Vol. 3), Greenwich, CT: JAI Press.

Jaiswal, A. K. (2008). Customer satisfaction and service quality measurement in Indian call centres. Managing Service Quality, 18(4), 405-416. http://dx.doi.org/10.1108/09604520810885635

Kang, G. D., \& James, J. (2004). Service quality dimensions: An examination of Gronroos's service quality model. Managing Service Quality, 14(4), 267-277.

Kilibarda, M., Zečević, S., \& Vidović, M. (2012). Measuring the quality of logistic service as an element of the logistics provider offering. Total Quality Management \& Business Excellence, 23(11-12), 1345-1361. http://dx.doi.org/10.1080/14783363.20 12.704279

Kotler, P., \& Armstrong, G. (2012). Principles of Marketing. Pearson.

Li, T., Chen, Y., \& Li, T. (2018). Pricing Strategies of Logistics Distribution Services for Perishable Commodities. Algorithms, 11, 186-200. DOI:10.3390/a11110186

Liu, W. H., \& Xie, D. (2013) Quality decision of the logistics service supply chain with service quality guarantee. International Journal of Production Research, 51(5), 1618-1634. http:// dx.doi.org/10.1080/00207543.2012.720390

Mohr, L. A., Bitner, M. J., \& Booms, B. H. (1995). The role of employee effort in satisfaction with service transactions. Journal of Business Research, 32(3), 239-252.

Oliver, R. L. (1997). Satisfaction - A Behavioural Perspective on the consumers. New York: McGraw-Hill.

Panayides, P. M. (2007). The impact of organizational learning on relationship orientation, logistics service effectiveness and performance. Industrial Marketing Management, 36, 68-80. http://dx.doi.org/10.1016/j.indmarman.2005.07.001

Parasuraman, A., Zeithaml, V. A., \& Berry, L. L. (1988). SERVQUAL: A multiple - item scale for measuring consumer perceptions of service quality. Journal of Retailing, 64, 12-40.
Parasuraman, A., Zeithaml, V. A., \& Berry, L. L. (1991). Refinement a Reassessment of SERVQUAL scale. Journal of Retailing, 67, 420-450.

Rahman, S. U. (2008). Quality management in logistics services: A comparison of practices between manufacturing companies and logistics firms in Australia. Total Quality Management \& Business Excellence, 19(5), 535-550. http://dx.doi. org/10.1080/14783360802018202

Tse, Y. K., \& Tan, K. H. (2011). Managing product quality risk in a multi-tier global supply chain. International Journal of Production Research, 49(1), 139-158. http://dx.doi.org/10.108 0/00207543.2010.508942

Tuyen, N. T. T. (2012). Factors affecting customer satisfaction of logistics service of the logistics companies in HoChiMinh city. Masters thesis, HoChiMinh City, Vietnam: University of Economics HoChiMinh City.

Vinh, V. T. (2007). Service quality in maritime transport: conceptual model and empirical evidence, Asia Pacific. Journal of Marketing and Logistics, 20(4), 493-518.

Vinh, V. T., \& Grewal, D. (2005). Service Quality in Seaports. Australian Maritime College.

Vuong, B. N., \& Giao, H. N. K. (2019). The impact of brand globalness on consumers purchase intention and the moderating role of consumer ethnocentrism an evidence from Vietnam. Journal of International Marketing, 32(1), 47-68. DOI: 10.1080/08961530.2019.1619115.

Wirtz, J. (2001). Improving the measurement of customer satisfaction: a test of three methods to reduce halo. Managing Service Quality, 11(2), 99-112. http://dx.doi. org/10.1108/09604520110387239

Zairi, M. (2000). Managing customer satisfaction: a best practice perspective. The TQM Magazine, 12(6), 389-394. http://dx.doi. org/10.1108/09544780010351670

Zeithaml, V. A. (1988). Consumer perceptions of price, quality, and Value: A means-Ends model and synthesis of evidence. Journal of Consumer Marketing, 52(3), 2-22.

Zeithaml, V. A., \& Bitner, M. J. (2000). Services Marketing: Integrating Customer Focus across the Firm. New York, NY: McGraw-Hill. Irwin. 